\title{
Antecedents of Dividend Payout Among Listed Non-Financial Companies listed in Nairobi Securities Exchanges, Kenya
}

\author{
Simion K. Biwott ${ }^{1}$, Tobias Olweny, Ph.D ${ }^{2}$ \\ ${ }^{1}$ Post Graduate Student, School of Business, Jomo Kenyatta University of Agriculture and Technology \\ ${ }^{2}$ Lecturer School of Business, Jomo Kenyatta University of Agriculture and Technology
}

\begin{abstract}
The objective of this study was to establish the antecedents of dividend payout among listed non-financial Companies listed in Nairobi Securities Exchanges, Kenya, with four specific objectives; to establish the effect of profitability, capital expenditure, leverage and liquidity on dividend pay-out of listed non-financial companies in NSE. The study was founded on Modigliani and miller hypothesis, signalling hypothesis, birds in hand fallacy, Agency and clientele policy. Using correlation research design, the study examined the antecedents of dividend pay-out of listed non-financial companies listed in Kenya for the period 2008 to 2019. The result showed a positive and significant relationship between dividend pay-out ratio and profitability, liquidity and leverage. It also shows negative association between dividend pay-out and capital expenditure. It was concluded that capital expenditure significantly influences dividend paid out negatively. Interest payment for long term debt takes priority as a charge on the profit made by the company. An improvement of a company's liquidity would lead to a better compensation to shareholder inform of dividend distributions. Listed companies therefore are expected to pay dividends when the companies are performing well because otherwise shareholders may question the proceeding of the announced profit or results to signaling effect. Listed companies should arrange the financing of capital expenditure so as ensure shareholder remains at an advantage and enable the company to recover its cost on capital and expected returns.
\end{abstract}

\section{KEYWORDS: Dividend Pay-out Ratio, Profitability, Leverage, Capital Expenditure and Liquidity.}

\section{INTRODUCTION}

There has been persistent interest among finance scholars on the role of dividend pay-out in corporate companies (i.e. see Lintner, 1956; Miller and Modigliani, 1961; Baker, Farrely and Edelman, 1985; Allen and Michaely, 1994) as cited in Rafique (2012). According to Oruru (2010) the amount of earnings which is distributed amongst the shareholders is known as dividend. The dividend payment is an important component in an organization since it aims at providing a solution to dividend puzzle on whether the payment of dividend increases or reduces firm's value and more so it's a financing strategy whereby if a company distributes huge amount in form of dividend, then there is need to look for alternative sources of finance when pressed by some needs in future. Dividend pay-out is of concern to both investors and management since it can influence company's stock valuation which will impact the resultant firm's value. More so the amount of annual dividend can influence the asset pricing, capital mix and investment decision. Past scholars such as Myres (1977) as cited in Ardestani et al., (2012), perceived the amount of dividend to be received by the ordinary shareholders to be influenced by profitability, risk, ownership, size, investment opportunity and firm growth opportunities to significantly influence the amount of dividend paid by any corporate company.

Finance theorists and corporate experts are in congruence that the main theme of all firms is shareholder's wealth and profit maximization (Ndili \& Muturi, 2015). This calls for development of vibrant and robust financing, working capital, investment and dividend decisions. Earlier theoretical proponents purported an existence of perfect market though it was refuted by Gordon (1963) who perceived investors to be more concerned by both dividend and capital gain as stipulated in bird in hand theory. To Gordon dividend policy impacted positively corporate valuation and most investors were risk averse thus they opted cash payment instead of capital gains. These claims were refuted by the proponents of tax preference theory whereby investors had preference for capital gains rather than pay corporate tax rate. Therefore, there is no cemented conclusion on how, why, and how much ought to be paid as dividend to investors in Nairobi securities exchange.

\section{Nairobi Securities Exchange}

NSE was founded in 1920s as a platform for British colonialists to trade their shares. At this time trading was not regulated and market operated informally. There was limited participation of locals since their income capacity was low 
and their policies that discriminated against them (Ngugi, 2013). The market was fully operationalized around 1954 after formation of a society of stock brokers. Later Capital Market Authority (CMA) was formed with the main purpose of developing and promoting securities exchange market in Kenya. This was through development of regulations and trading platforms that would enhance investor confidence and minimize the risk exposure. In 2000 Central Depository System (CDS) was introduced so as to enhance liquidity in stock market.

In 2011 NSE changed its name to be Nairobi Securities Exchange in preparedness for trading of different securities and provide clearing services, derivative platforms and other related securities (NSE, 2013). NSE acts as platform for raising capital, provision of liquidity of financial assets and source of economic performance information. Through it there has been notable growth in equity, debt and derivatives trading. Currently there are 68 listed companies grouped into 11 sectors that are financial, utilities, consumer discretionary, energy, healthcare, industrials, technology, telecommunication, materials and real estate. The current study was limited to investigation of determinants influencing dividend pay-out of Non-financial Companies listed companies in NSE.

\section{MAIN OBJECTIVE}

The aim of the study was to establish antecedents of dividend payout ratio of listed non-financial companies in NSE, Kenya.

\section{A. Specific objectives}

i) To establish the effect of profitability on dividend payout of listed non-financial companies in NSE, Kenya.

ii) To determine the effect of capital expenditure on dividend pay-out of listed non-financial companies in NSE, Kenya

iii) To find out the effect of leverage on dividend pay-out of listed non-financial companies in NSE, Kenya

iv) To establish the effect of liquidity on dividend pay-out of listed non-financial companies in NSE, Kenya

\section{THEORETICAL REVIEW}

\section{A. Modigliani and Miller Hypothesis}

This hypothesis was documented by Modigliani and Miller in 1958. The hypothesis argues that in an efficient market there are no transaction, taxes, bankruptcy and taxes since all stakeholders have equal access to information that may guide in decision making. The value of firm is not dependent on leverage because every firm's investment decision is solely dependent in the choice of their asset class. To attain financing optimality then a balance between interest costs and floatation cost associated with issuing new debt. Further, they purported that profitability and risk are firm value determinants and not capital structure. Indeed, investment decision is mainly determined by the arbitrage opportunities which exist in any viable investment opportunity. Therefore, investors will tend to dispose share of highly valued entities and invest in under-priced companies (Mwangi, 2016).

Due to investors' rationality behaviour Modigliani and Miller (1958) purported that there exists an inverse relationship between cost of equity and gearing ratio and the investors are unwilling to take any risk which they cannot be compensated. In case when tax rate is zero, then it will be hard for any firm to obtain optimal capital structure. Further, Alifani and Nugroho (2013) argued that there are high chances of using debt financing because of the advantages associated with corporate taxes.

The theory is not void of criticism more so because of the assumptions in which the theory is based on. In fact, it is so hard to have an operating environment void of transaction costs, bankruptcy costs and agency conflicts (Mwangi, 2016). An increase in market to book value ratio of listed companies may trigger increase in firm value and consequently enhance firm's ability to borrow. Debt financing would demand for regular commitments in servicing of loans that may have effect on available cash for payment of dividends.

\section{B. Signaling Hypothesis}

Signaling hypothesis theory was developed by Spence (1973). The theory proposes that dissemination of positive information publicly is meant to portray current and future positive performance. Corporation information is shared by respective companies to achieve desired objectives that may be short, medium or long term (Bini, Giunta \& Dainelli, 2013). Regular flow of information is meant to optimize information access costs and minimize level of information asymmetry. There are cases of level of information asymmetry signaling changes in stock market. According to Spence (1973) the level of information hoarding is dependent on level of influence an institution controls on investors decision making. Moreover, there is need for regular information update so as to enhance investor confidence through quality of decision making.

This is a theory which asserts that announcement of increased dividend payments by a company gives strong signal of positive trend. Companies use dividends to share profits with stockholders and when doing so, they can decide to issue a dividend when ploughing profits back into the company for development and growth is not the best option, is not necessary or not practical. At the time officials make the decision to offer a dividend, they usually make an announcement, providing information about the amount and date so shareholders know what to expect (Spence, 1973).

These announcements are closely anticipated and followed because investors believe they can provide information about the company's financial health. Generally, dividend signalling is done by the company when it changes the amount of dividend to be paid to shareholders. Miller and Modigliani (1961) work sustain that, in a perfect capital 
market, a firm value is independent of the dividend policy. However, some years later, Bhattacharya (1979), John and Williams (1985) and Miller and Rock (1985) developed the signalling theory classic models, that linked dividend policy to information asymmetry. So, a dividend increases signals an improvement on a firm's performance, while a decrease suggests a worsening of its future profitability. Consequently, a dividend increase (decrease) should be followed by an improvement (reduction) in a firm's profitability, earnings and growth. Moreover, there should be appositive relationship between dividend changes and subsequent share price reaction. One of the most important assumptions of the signalling theory is that dividend change announcements are positively correlated with share price reactions and future changes in earnings. According to Miller and Rock (1985) signalling theory is also banked by the assumption that information is not equally available to all parties at the same time, and that information asymmetry is the rule. Information asymmetries can result in very low valuations or a suboptimum investment policy. Signalling theory states that corporate financial decisions are signals sent by the company's managers to investors in order to shake up these asymmetries. These signals are the cornerstone of financial communications policy. In this case, managers know more than investors, so investors will find "signals" in the managers' actions to get clues about the firm. So, the theory simply suggests that firm's announcements of an increase in dividend pay-outs act as an indicator of the firm possessing strong future prospects.

\section{Birds in Hand Fallacy Theory}

This theory was brought forth by Gordon and Linter (1963) it is based on certainty of dividends and capital gains among individual investors. They argued that failure to pay all earnings as dividends is precipitated by availability of investment projects which have net present value, an undertaking of such projects increases shareholders through capital gains. Moreover, the theory perceives that risk averse investors has more preference for dividends against capital gains, receipt of dividend income has certainty when compared with capital gains which can be received upon surpassing the risk in which the investment is exposed to and if a company is highly concentrated with investors who have preference for certain income then there are high chances of high dividend payment and vice versa.

According to Easterbrook (1984), the bird in hand effect will occur if investors utilize their dividends for consumption or to acquire treasury bills, but if they reinvest the received dividends in the same or a different business, they subject their cash (minus taxes paid) to the same risks as if there had been no dividends, the bird in hand effect will not occur until the business alters its in-house policies. However, just because investors are ready to wait for their dividends rather than receive them right away does not mean they do not want them. Some investors (legally protected shareholders) are ready to wait for future dividends in the case of attractive investment possibilities, and this is common in fast-growing companies because fast-growing companies pay smaller dividends than slow-growing companies (La Porta, De Silanes, Shleifer, \& Vishny, 2000). Furthermore, La Porta, et al., (2000) explained, on the contrary, regardless of investment opportunities, some investors (poorly protected stockholders) are want to take dividends as much as they can get, most possibly because the investors think, dividends (bird in the hand) are better than retained earnings (bird in the bush) that might be never to realize as future dividends (bird can fly away), if investment misallocation happened. This is similar with finding by Brennan and Thakor (1990) that, if the effective personal income tax rate on dividends is not too high, then the stockholders with low ownership, will prefer to take dividends.

\section{Agency Theory}

According to Jensen and Meckling (1976) all corporate organization are mostly run by management which acts on behalf of shareholders. There are different parties which are involved in running of companies and they must be involved in making dividend decisions. For example, the management is interested in satisfying their needs through huge payment which will increase the expenses and consequently reduce the amount entitled to the shareholders. In addition, regulators may increase the minimum capital requirements. This may alter the proportion held inform of capital. Providers of debt capital may increase interest charges that may decrease the amount of earnings attributable to shareholders. Agency theory is associated with creation of agency problem that is manifested in risk sharing among different cooperate entities (Arrow, 1971). Different stakeholders in an organization have different levels of risk tolerance hence their actions would be different. Principal stakeholders may be willing to undertake higher risks so as to achieve more economic gains as compared to agents who may have short term goals that may deter them from undertake high risk investments. These differences in risk sharing would amplify conflict in different groups. According to Ross (1973) agency conflicts are associated with incentives while Mitnick (1975) attributed it institutional framework. Ross alluded agency problems were associated with compensation. Institutional structure argument by Mitnick was crucial in development. According to this proposition organization are founded on agency and grows as they seek agency reconciliation. Alchian and Demsetz (1972) and Jensen and Meckling (1976) organization creates contracts that supports their production process. Corporate entities are legal entities based on contractual relationships. Principal agency partnership is a relationship based on self interest that causes conflicts. Thus, monitoring and agency costs are introduced to mitigate them. In this contracts, structure, level of information asymmetry 
and labour market share has significant role in achievement of ownership structure.

According to Fama and Jensen (1983) decision making process can be segregated into decision management and decision control and agents has crucial role throughout decision making process. They are segregated dependent in complexity and non-complexity of decision-making process. In complex situations, agency problems arise since management decision process is not initiated by the real owners of corporate entities. Hence, the need to control decision making process to enhance survival of a firm.

\section{E. Clientele Dividend Policy Theory}

According to Petit (1977) there are different groups of clients who are attracted to invest in a given company. These groups of individuals have different characterisation which will make them have unique preference of dividend policies for example among the retiree they may have more preference on receiving annual dividend as such to increase their source of meagre earnings. In contrast young investors would prefer reinvestment as such to minimize the amount of taxes which they ought to pay from their total earnings.

According to Easterbrook (1984) by view of clientele effects, if some investors are in different tax positions from others (for example, some hold tax-sheltered funds while others are taxed at ordinary rates), the different groups will have different preferences for dividends, or it could be said that the taxed group would prefer to take profits as capital gains; the untaxed group would be indifferent. By Baker and Haslem (1974), in their study had found that, dividends is the most desired factor by investors, because dividends are assumed less risky than the capital gains expected from reinvested earnings. Also, there is an informational content behind dividends or dividend changes, because it can provide an indication of management's judgments concerning the firm's future earnings expectations. But Baker and Haslem (1974) also found that, investors cannot be classified in a single homogeneous class, because certain types of stocks prove attractive to particular types of investors, which was created clientele effect (Miller \& Modigliani, 1961). Furthermore, Baker and Haslem (1974) classified the investors based on their behaviour and classes in two distinct types, those who seek dividends and those who seek capital appreciation. The investors who seek dividends are investors which have tendency for using dividends and financial stability as the basis for their investment decision, also, they are known as a risk-averse investor. Whereas, investors who seek capital appreciation are investors which have tendency for using future expectations as the basis for their investment decision, or in the other words, these investors are willing to sacrifice their current dividends for future price appreciation.

\section{EMPIRICAL REVIEW}

\section{A. Profitability and Dividend Payout}

Mehta (2012) investigated the determinants of dividend payout policy among companies listed in Abu Dhabi securities in 2005-2009. The study hypothesized that dividend policy is influenced by firm size, profitability, price earnings ratio, leverage and liquidity. Profitability was operationalized as return on equity, return on assets and Earnings per share. Census sampling was used to select all 44 companies which were listed in Abu Dhabi in 2005-2009. Secondary data was collected from audited annual financial statements. Both correlation and step wise regression analysis were used to analyse the data. Profitability had negative and significant effect on dividend policy. Moreover, the most profitability had the highest explanatory power of the changes in dividend policy among the companies listed in UAE. Even though the study applied step wise regression it ignored the period and group effects and it would have been appropriate to use panel regression analysis with pooled, random or fixed effects regression analysis. Lee, Isa and Lim (2012) evaluated dividend changes and future profitability among companies listed in Malaysia. Multiple regression model was fitted on secondary data. The study found that although dividend was influenced by firm earnings it was weakly related with earnings for one year and there was no relationship for earnings beyond one year. In addition, there was weak evidence that dividend influenced firm's profitability.

Ahmed (2015) posited that profitability and liquidity had significant influence on dividend payout in the banking sector. Ahmed operationalized profitability as return on equity, return on assets and earnings per share. Bivariate and multivariate techniques analysed the data. Inverse significant effect of ROE, ROA and dividend payout was documented. Moreover, EPS positively affected dividend payout. Muchiri (2006) studied antecedents of dividend payout. Using questionnaires, data were collected form the respective companies finance directors. Among other factors, current and expected profitability was ranked first in determining whether to pay dividend which using multiple regressions was found to be significantly influencing the decision on whether to pay dividend.

Wasike and Ambrose (2015) also carried a research to determine what influences dividend policy of Kenyan companies for a period of 11 years ending 2014. The independent variable under investigation was profitability cash flow and tax. Panel regressions technique was used for data analysis for the sixty companies listed in NSE. There was positive significant co-movement between profitability and dividend payout.

An investigation on the relationship between dividend payout ratio and capital structure on industrial and allied listed companies in Nairobi securities exchange was carried out by Sang, Shisia, Gesimba and Kilonzo (2015). Purposive 
sampling was adopted to sample 16 companies listed in industrial and allied segment from 2007 to 2011. Inverse effect of leverage, retained earnings and dividend payout. These results concluded that there is need to evaluate factors associated with both leverage and retained earnings and minimize their influence so as to increase the amount of dividend available to shareholders.

King'wara (2015) fitted Tobit regression analysis the study investigated on the effect of earnings, retained earnings, firm size, and leverage and growth opportunities on dividend policy in Kenya. Panel data was retrieved from annual financial statements of listed companies from 2008 to 2012. Results of the study revealed positive and non-significant relationship between retained earnings, earnings, MBV and dividend payout. Although firm size, change in sales and leverage had inverse relationship only change in sales had significant influence. The study concluded on the need to evaluate alternative factors which could impact on dividend payout and also the need to investigate how the selected factors affected individual sector in NSE.

Mui and Mustapha (2016) studied determinants of dividend payout in Malaysia. In this study it was hypothesized that dividend payout was determined by liquidity, MBV, ROE, leverage and firm size. Panel research design was adopted and five-year data was collected from annual audited financial statements from 2007 to 2011. Purposive sampling was used to exclude companies listed in finance sector owing to their unique in capital requirement and regulatory framework. Results of the study revealed positive and non-significant relationship between liquidity, leverage and size while ROE had negative relationship with payout. On the other hand, MBV had positive and significant relationship with dividend payout.

\section{B. Capital Expenditure and Dividend Payout}

Tahir, Ullah and Mahamood (2015) examined banks dividend payout and investment policy in Pakistan. Secondary data was collected from audited annual statements of commercial banks listed in Karachi Securities Exchange in 2004-2013. Bivariate and multivariate techniques analyzed the data. Though investment decision was related to financing decision it was not related to dividend policy. They argued no single theory can explain solely the impact of investment decision on dividend payout policy, though balancing, pecking order and signalling theories can jointly explain the impact of investment decision on dividend policy.

Jóźwiak (2015) hypothesed that dividend policy was determinants by leverage, profitability, liquidity, firm size and risk, correlation research design was adopted. Panel data was collected from annual financial statements from 2000 to 2002. Regression model was fitted. The study revealed that leverage and liquidity had negative non-significant influence on dividend policy. In contrast, profitability, firm size and price earnings ratio had positive and non-significant relationship with dividend policy.

Periyathampy (2012) investigated determinants of dividend payout ratios amongst companies listed in Colombo securities exchange in Sri Lanka. The study hypothesed that dividend payout ratio was determined by growth in sales (GS), earnings per share (EPS), price earnings ratio (P/E), MBV, cash flow $(\mathrm{CF})$, leverage, liquidity and ROA. Correlation research design was adopted. Panel data was collected from 28 financial statements of listed companies in 2010 to 2011. Regression model was fitted. Results of the study revealed positive and significant relationship between GS, EPS, MBV, LIQ and ROA. In contrast there was inverse effect of P/E, $\mathrm{CF}$, leverage and dividend payout ratio.

A Nigerian case on investigation of factors influencing dividend Payout was carried out by Kajola, Desu and Agbanike (2015). The study hypothesed that their dividend payout ratio was influenced by profitability, firm size, board size and leverage. Panel research design was adopted and secondary data of 20 non-financial listed companies was collected for periods from 1997 to 2011. Regression model was fitted. From the finding's dividend payout was contingent to profitability, dividend volatility and firm size. Moreover, it was inversely affected by GS, liquidity, leverage and tangibility.

Soondur, Maunick and Sewak (2016) investigated determinants of dividend policy amongst firms listed in Mauritius. The study hypothesized that dividend payout is influenced by EPS, net income, retained earnings, cash and cash equivalents, firm size and leverage. Panel research design was adopted; purposive sampling was used to select 30 listed companies from 2009 to 2013. Regression model was fitted. Dividend payout ratio was positively related to EPS and negatively to net income. Further, there was no significant contribution of leverage, retained earnings, cash and cash equivalents on dividend payout.

\section{Leverage and Dividend Payout}

Asif, Rasool and Kamal (2010) studied leverage and dividend payout in KSE. Purposive sampling technique was used to select 403 companies which were listed in 2002-2008. Through regression modelling inverse contribution on dividend payout was reported. Data over a long period may have been considered so as to manage challenges associated with use of short panels. KSE and NSE operates in different business environment thus none of its findings may be replicable.

Al-Malakwi (2008) examined the factors influencing corporate dividend policy in Jordanian. Secondary panel unbalanced data was collected among 1137 yearly firms in1989-2003. Probit estimation was used to examine the effect of firm size, profitability, age and leverage. Dividend payout was positively affected by size, age and profitability but inverse to leverage. The study concurred with pecking 
order and agency theories. Diagnostic tests may have been considered prior to modelling.

An Indian case studying antecedents of dividend payout was carried out by Labhane and Das (2015). Through correlation research design and purposive sampling technique a sample of 239 companies which were trading from 1994 to 2013 were considered. Trend analysis revealed variations in amount of dividend which was paid with decline trends registered during periods of financial crisis. Multiple regression analysis revealed positive and significant relationship between free cash flows (FCF) and dividend payout. In contrast an inverse relationship was reported amongst those firms which had high leverage and had more profitable investment opportunities. The results of this study supported signalling hypothesis, pecking order theory, firm life cycle and they did not support agency theory.

Khan and Ahmad (2017) evaluated dividend payout antecedents among pharmaceutical companies which are listed in Pakistan securities exchange. The study adopted panel research design and secondary was retrieved from annual financial statements over a five-year period from 2009 to 2014. Through regression modelling, dividend payout was influenced by type of audit, GS, liquidity, profitability, taxation and leverage. Inverse effect of leverage was linked to the need to contractual commitment to service debt charges regularly. The findings contravenes clientele dividend policy since stakeholders in an organization are heterogeneous.

A comparative analysis on capital structure cost of debt and dividend payout between New York and Shanghai securities exchanges was carried out by Jiang and Jiranyakul (2013). Panel research design was adopted and secondary data was collected from annual financial statement from 1992 to 2008. In general, multi regression analysis revealed that although debt financing, equity financing and cost of debt had significant influence on dividend payout in New York they had no influence in Shanghai securities exchange. Moreover, there was positive and insignificant relationship between debt financing, cost of debt financing and dividend payout ratio. Equity financing had positive and significant influence on dividend payout ratio. It was recommended that those companies which were listed in China should diversify their financing alternative as such to boost investor's confidence.

A Pakistan case studying antecedents of dividend payout was carried out by Ahmad and Muqaddas (2016). Panel research design was adopted; secondary data was collected over nineyear period from 2006 to 2014 . The study hypothesed that financial efficiency, safety, risks and profitability. Financial efficiency was operationalized as interest ratio, safety was measurement investment to total assets, risk was measured as nonperforming loans to gross loans and profitability was measured as return on assets. Dividend payout policy was positively affected by financial efficiency and risk. Further, safety and profitability inversely contributed on dividend payout ratio.

Musiega et al., (2013) investigated the determinants of dividend policies among non-financial companies listed in Nairobi securities exchange. Descriptive research design was adopted in the study and 30 non-financial companies which were listed from 2007 to 2012 were purposively selected. Profitability, growth opportunities, liquidity and current earnings were assumed to have influence on dividend payout. Firm size and business type were moderators. The study revealed positive and significant relationship between growth opportunities and dividend policies while liquidity had inverse and non-significant relationship with dividend payout ratio.

Nnadi, Wogboroma and Kabel (2012) studied dividend payout ratio antecedents in African securities markets. The study adopted correlation research design. Purposive sampling was used to draw 1742 companies from 29 African countries. Panel secondary data was collected from 1998 to 2009. The study revealed an inverse and non-significant relationship between agency cost, leverage and dividend payout ratio. In contrast there was a positive and nonsignificant relationship between government ownership, age and dividend payout ratio.

\section{Liquidity and Dividend Payout}

Ahmed (2014) examined the impact of liquidity on dividend policy among 30 listed commercial Banks in 2012. Although, the data was single period it was assumed to be a true representative of the historical patterns. Multivariate approach was used for data analysis. The study found a positive but non-significant relationship between liquidity and dividend payout ratio.

Kibet (2012) studied liquidity and dividend payout in Kenya using regression model. A positive but not significant relationship between liquidity and dividend policy was documented. From the findings it was implied that listed firms ought to maintain high levels of liquidity as such to be in a position to pay dividend when they fall due. Since the data was panel in nature it would have been appropriate to use pooled, fixed or random effects regression modelling as such to capture both time and group effects of each company.

Olang, Akenga and Mwangi (2015) studied contribution of liquidity on dividend payout in Kenya. Comparative causal research design was adopted and purposive sampling was used to select 30 companies which had consistently paid dividend from 2008 to 2012. The study revealed that profitability had the highest influence on dividend payout ratio as compared to working capital and FCF. The study concluded that there is need for listed companies to continuously monitor their cash flow operations and execute efficient management policies on their working capital.

Ahmed (2015) studied dividend payout policy antecedents in United Arab Emirates banking sector. Correlation research 
design was applied and purposive sampling was used to select 18 banks and secondary data was retrieved from annual financial statements for periods 2005 to 2012. Although, liquidity positively affected dividend payout there was inverse contribution of profitability. Since panel data was considered, there was need for documentation of diagnostic tests that supported the model deployed in the study.

\section{METHODOLOGY}

\section{A. Research design}

The study adopted correlation research design. Correlation research design is aimed at showing the causal relationship between variables of large amounts of data from the target population under study (Sekaran \& Bougie, 2013). It was appropriate for the current study because the study sought to show the antecedents of dividend payout ratio among companies listed in NSE.

\section{B. Target Population, Sample Procedure and Sample Size}

According to Kothari (2011) a complete enumeration of all individuals under consideration. In the current study all companies listed and actively trading in NSE formed the target population. Out of 68 companies listed in NSE and actively trading as at December 2019, purposive sampling technique was used to select 42 non-financial companies which had been actively trading in the past eleven years (2008-2019).

\section{Data and Data Collection Procedures}

The study adopted panel data that was sourced from NSE hand books, financial statements and specific company's websites. As indicated in the data collection sheets information sought was on profitability, capital expenditure, leverage, liquidity and dividend payout. Period under considerations was 2008 to 2019. Year 2008 was characterized by post-election violence that may have impacted on business operating practices.

\section{Data Analysis}

Collected data was processed and analyzed using Stata 14. A mix of descriptive statistics; mean, standard deviation, skewness and kurtosis and inferential statistics that include Product moment correlation and multiple regression were used. The resulting model is;

$\mathrm{Y}_{\text {it }}=\alpha+\beta_{1} \mathrm{X}_{1}$ it $+\beta_{2} \mathrm{X}_{2}$ it $+\beta_{3} \mathrm{X}_{3}$ it $+\beta_{4} \mathrm{X}_{4}$ it $+\dot{\varepsilon}$

Where.

$\mathrm{Y}$ - Is the Annual dividend paid,

$\alpha-$ is the regression constant term,

$\beta_{1}, \beta_{2}, \beta_{3}$ and $\beta_{4}$ - Are the regression coefficients

$\mathrm{X}_{1}=$ Profitability,

$\mathrm{X}_{2}=$ Capital expenditure,

$\mathrm{X}_{3}=$ Financial Leverage,

$\mathrm{X}_{4}=$ Liquidity and

$\dot{\varepsilon}=$ error term

\section{E. Operationalization of the Variables Profitability}

Profitability is the positive difference between revenue and operating costs of a corporation (Pandey, 2009). Corporate entities are formed with the intention of maximizing shareholder's wealth and profitability. Javeda, Raob, Akramc and Nazird (2015) argues that profitable organization should always exceed the cost of capital on their investment returns. Profitable corporations have higher odds of paying dividend as compared to non-profitable entities. Profitability may have positive or negative effect of dividend payout since some entities may retain more of it depending on their stages of growth. Profitability was operationalized as natural logarithms of earnings after tax.

\section{Capital Expenditure}

Capital expenditure is the annual budgetary allocation on acquisition and improvement of non-current assets. The amount allocated for capital expenditure on annual basis may minimize the dividend to be paid. This will depend on sources of financing for respective capital expenditure. Ardestan et al., (2013) document significant contribution of investment opportunity on dividend payout. Imran (2011) documented positive significant contribution of EPS, profitability, growth in sale, cash flows and firm size on dividend payout. Capital expenditure was operationalized as natural logarithms of annual capital expenditure.

\section{Leverage}

Leverage is the amount of financing in a corporate entity that is sourced from external sources. Debt financing will attract fees that are payable on regular basis and they may have negative implications if respective investment does not generate amount enough to cater for regular costs. Tamimi and Takhtaei (2014) a negative but insignificant relationship between financial leverage and dividend per share. The choice of OLS was not appropriate since they ought to have considered period and group effects jointly. Farahani and Jhafari (2013) found a positive but insignificant relationship between debt-to-equity ratio and dividend per share. Leverage was operationalized as natural logarithms of interest paid per annum.

\section{Liquidity}

Liquidity is the capacity of an entity to convert its resources into liquid cash. The faster the conversion period the higher the liquidity. Igan, Paulo and Pinheiro (2010) found a positive significant contribution of liquidity on dividend payout. Moreover, shareholder's concentration had the strongest positive moderating effect on the relationship between dividend policy and stock liquidity. Liquidity showed no significant association with dividend payment ratio, according to Komrattanapanya and Suntrauk (2013). However, dividend payout ratio was inversely related to investment possibilities, financial leverage, and sales growth. 
Liquidity was operationalized as natural logarithms of (Net Income + Depreciation \& Amortization + Other Noncash Adjustments + Changes in Non-cash Working Capital).

\begin{tabular}{lll}
\multicolumn{2}{l}{ Operationalization of the Variables } & \\
\hline Variable & Definition & Measures \\
\hline $\begin{array}{l}\text { Dividend } \\
\text { pay out }\end{array}$ & $\begin{array}{l}\text { Annual dividend to } \\
\text { ordinary } \\
\text { shareholders }\end{array}$ & $\begin{array}{l}\text { Annual dividend } \\
\text { paid }\end{array}$ \\
\end{tabular}

\begin{tabular}{|c|c|c|}
\hline Profitability & $\begin{array}{l}\text { Total earnings less } \\
\text { tax }\end{array}$ & $\begin{array}{l}\text { Total annual } \\
\text { earnings after tax } \\
\text { (EAT). }\end{array}$ \\
\hline $\begin{array}{l}\text { Capital } \\
\text { expenditure }\end{array}$ & $\begin{array}{l}\text { This is the total } \\
\text { amount spent per } \\
\text { annum in the } \\
\text { acquisition, } \\
\text { replacement of firm } \\
\text { assets meant for long } \\
\text { term use. }\end{array}$ & $\begin{array}{l}\text { Annual capital } \\
\text { expenditure }\end{array}$ \\
\hline Leverage & $\begin{array}{l}\text { This refers to the } \\
\text { total annual interest } \\
\text { paid per annum }\end{array}$ & $\begin{array}{l}\text { Total annual } \\
\text { interest charges on } \\
\text { long term debt }\end{array}$ \\
\hline \multirow[t]{3}{*}{ Liquidity } & $\begin{array}{l}\text { Refers to cash flow } \\
\text { per share. }\end{array}$ & $\begin{array}{ll}\text { Net Income } & + \\
\text { Depreciation } & \& \\
\text { Amortization } & +\end{array}$ \\
\hline & & Other Noncash \\
\hline & & $\begin{array}{l}\text { Adjustments + } \\
\text { Changes in Non- } \\
\text { cash } \quad \text { Working } \\
\text { Capital) }\end{array}$ \\
\hline
\end{tabular}

\section{F. Diagnostic Tests}

Panel modelling is based on several assumptions on heteroscedasticity, normality, serial correlation, Multicollinearity and Hausman test among other tests.

\section{G. Stationarity}

Stationarity is a situation in which statistical features of variables under examination remains constant within the period under examination. Classical models should be fitted on stationary data otherwise it spurious model will be fitted. In this study stationarity was examined through use of Augmented Dickey Fully (ADF) test. The tests assume that the data is stationary against an alternative of non-stationary (Stock \& Watson, 2018).

\section{H. Normality Test}

According to Hansen (2020) normally distributed data portrays a bell shape with mean of zero and standard deviation of 1. Even though, there are graphical and statistical tests that can be applied for normality test the current study used Jarque Berra test. According to Baltagi (2005) Jarque Berra test assumes that data is normally distributed and if $\mathrm{P}$ value $<0.05$ the data is not normally and there is need for transformation so as to achieve normality. Data can be transformed through natural logarithms, use of inverse or square roots.

\section{Multicollinearity}

Multicollinearity is a condition in which explanatory variables are highly related (Wooldridge, 2012). Variance inflation factors (VIFs) and tolerance were applied for its examination. There is multicollinearity among variables if VIF is more than 10 and tolerance limits less than 0.1. To manage it then there may be need for model rectification and dropping correlated while modelling.

\section{J. Heteroscedasticity}

According to Gujarati and Porter (2009) heteroscedasticity is a condition in which the error terms of a regression model have no equal variance. The assumption can be examined through use of modified Wald test and if its $p$ value $<0.05$. Then there is need to fit Feasible Generalized Least Squares Model (FGLS) or ordinary least square model with robust standard errors (Baltagi, 2005).

\section{K. Serial Correlation}

According to Wooldridge (2012) autocorrelation is a situation in which current and past period error terms of variables under examination are related. In this study it may be examined through use of Wooldridge Drukker test. If $p$ value $>0.05$, then there was no serial autocorrelation (TorresReyna, 2007).

\section{Hausman Test}

Fixed-effects models are a class of statistical models in which the levels (i.e., values) of independent variables are assumed to be fixed (i.e., constant), (Greene, 2008). Random-effects models are statistical models in which some of the parameters (effects) that define systematic components of the model exhibit some form of random variation. Statistical models always describe variation in observed variables in terms of systematic and unsystematic components. According to Greene (2008) fixed effects model assumes different groups have different intercepts and random effects model assumes that the groups have different error terms. Hausman (2008) argued that there is always a conflict between the choice of random and fixed effects model which can be resolved through the use Hausman test which hypothesis that the study data has fixed effects.

\section{RESULTS AND DISCUSSIONS}

The following are the results from the secondary data collected from 42 listed non-financial companies in NSE in 2008 to 2019. Descriptive analysis, diagnostic tests and panel data analysis is presented. Since the data had both cross sectional and time series characteristics panel data approach was used. Prior to the data analysis the data was transformed using log transformation. 


\section{A. Panel Data Descriptive Analysis}

Results in Table 4.1 shows that the average annual dividend is 15.45 with an average deviation of 1.504 . The average profitability is 13.407 with a standard deviation of 2.890 which is higher variability as compared to the dividend that was distributed. Capital expenditure averaged a value of 16.069 which is higher than the profit made. Leverage had mean of 15.077 whereas liquidity was found to have an average of 13.201 with a standard deviation of 0.985 . Normality examination indicated that the variables under examination were not normal since their respective $p$ values for Jarque Berra were less than 0.05.

Non-normality was in agreement with Githira, Muturi and Nasieku (2019) who reported that financial data among listed companies in East Africa securities Exchanges (EASE) was not normal. This is mainly because of differing features of listed companies such as size which may have implications on financial decisions adopted. These results contravene Wanjau, Muturi and Ngumi (2018) who reported that transparency characteristics of listed companies in EASE were normally distributed. This was not in agreement with Mwangi, Muturi and Ngumi (2016) who reported nonnormality of financial structure of listed companies in EASE.

Table 4.1. Descriptive Statistics

\begin{tabular}{|c|c|c|c|c|c|}
\hline & $\begin{array}{l}\text { Annual } \\
\text { Dividend } \\
\text { paid }\end{array}$ & $\begin{array}{l}\text { Profit } \\
\text { ability }\end{array}$ & $\begin{array}{l}\text { Capital } \\
\text { Expend } \\
\text { iture }\end{array}$ & $\begin{array}{l}\text { Leve } \\
\text { rage }\end{array}$ & $\begin{array}{l}\text { Liqu } \\
\text { idity }\end{array}$ \\
\hline Mean & 15.45 & 13.41 & 16.07 & 15.08 & 13.20 \\
\hline $\begin{array}{l}\text { Maxi } \\
\text { mum }\end{array}$ & 17.42 & 16.57 & 22.03 & 0.30 & 5.06 \\
\hline $\begin{array}{l}\text { Minim } \\
\text { um } \\
\text { Std. }\end{array}$ & 12.5 & 1.00 & 13.22 & 0.11 & 1.00 \\
\hline Dev. & 1.504 & 2.89 & 2.075 & 0.081 & 0.985 \\
\hline $\begin{array}{l}\text { Skewn } \\
\text { ess }\end{array}$ & 1.43 & 1.90 & 1.52 & 2.56 & 0.41 \\
\hline $\begin{array}{l}\text { Kurtos } \\
\text { is }\end{array}$ & 7.62 & 6.64 & 5.04 & 12.82 & 3.57 \\
\hline $\begin{array}{l}\text { Jarque } \\
\text {-Bera }\end{array}$ & 309.42 & 341.49 & 741.20 & $\begin{array}{l}185.9 \\
1\end{array}$ & $\begin{array}{l}254.7 \\
6\end{array}$ \\
\hline $\begin{array}{l}\text { Probab } \\
\text { ility }\end{array}$ & 0.00 & 0.00 & 0.00 & 0.00 & 0.00 \\
\hline $\begin{array}{l}\text { Obser } \\
\text { vation }\end{array}$ & & & & & \\
\hline $\mathrm{s}$ & 421 & 421 & 421 & 421 & 421 \\
\hline
\end{tabular}

\section{B. Correlation Analysis}

Correlation analysis results are shown in Table 4.2. Profitability positively contributed to annual dividend pay. This implies an increase in profit would lead to an increase the value of annual dividend paid. There was an inverse but significant relationship between annual dividend and capital expenditure in the Kenyan companies. This implies that an increase in capital expenditure would lead to fall in the amount of dividend paid.

There was a positive and significant relationship between leverage and annual dividend paid. This implies that an increase in leverage increase amount of annual dividend paid; it can be deduced that Kenyan companies invest borrowed funds on activities which are increasing annual dividend. There was a strong positive and significant relationship between annual dividend paid and liquidity, this implies that companies that are more liquid are expected to be large amount dividend as compared to those that are experiencing liquidity problems. Therefore, there is a need to examine the working capital decision as such to counter its impact on liquidity position of the companies. The odds of multicollinearity were low since none of predictors had correlation coefficient higher than 0.7 with each other.

Table 4.2. Correlation Analysis

\begin{tabular}{|c|c|c|c|c|c|}
\hline & $\begin{array}{l}\text { Annual } \\
\text { dividen } \\
\text { d }\end{array}$ & $\begin{array}{l}\text { Profita } \\
\text { bility }\end{array}$ & $\begin{array}{l}\text { Capit } \\
\text { al } \\
\text { expen } \\
\text { diture }\end{array}$ & $\begin{array}{l}\text { Leve } \\
\text { rage }\end{array}$ & $\begin{array}{l}\text { Liqu } \\
\text { idity }\end{array}$ \\
\hline $\begin{array}{l}\text { Annual } \\
\text { dividend }\end{array}$ & 1 & & & & \\
\hline $\begin{array}{l}\text { Profitabil } \\
\text { ity } \\
\text { Capital } \\
\text { expenditu }\end{array}$ & $.573 * *$ & 1 & & & \\
\hline re & $-.656 * *$ & -0.01 & 1 & & \\
\hline Leverage & $.537 * *$ & $\begin{array}{l}0.093 \\
.187 *\end{array}$ & -0.057 & 1 & \\
\hline Liquidity & $.716^{* *}$ & $*$ & 0.029 & .089 & 1 \\
\hline
\end{tabular}

\section{Diagnostic Analysis}

Diagnostic tests were carried out before modelling to evaluate the most appropriate model to fit in the study. Tests carried out include stationarity, Hausman, multicollinearity and heteroscedasticity among others.

\section{Stationarity Test}

Unit roots was carried to examine the stationarity of variables under examination. ADF stationarity was used. As shown in Table 4.3 the null hypothesis for non-stationarity or presence of unit roots was rejected since $\mathrm{p}$ values were less than 0.05 for all variables. Consequently, it was concluded that annual dividend paid, profitability, capital expenditure, leverage and 
liquidity were stationary. The findings supported Wairimu, Muturi and Olouch (2019) who found firm financial characteristics of listed non-financial companies in NSE to be stationary.

Table 4.3. ADF Stationarity Test

\begin{tabular}{lll}
\hline Variable & Statistic & P value \\
\hline Annual Dividend Paid & 106.82 & 0.00 \\
Profitability & 120.52 & 0.00 \\
Capital Expenditure & 152.63 & 0.00 \\
Leverage & 185.63 & 0.00 \\
Liquidity & 184.56 & 0.00
\end{tabular}

\section{Breusch-Pagan Lagrangian Multiplier Test}

Having described the data, the study carried out panel data diagnostic tests. Results in Table 4.4 revealed that the pooled effects regression was the most appropriate model when the dependent variable was annual dividend because the $p$ value was more than 0.05 (insignificant). Panel data analysis modelling was applied.

Table 4.4. Chi-Square values for the Breusch -Pagan LM Test

\begin{tabular}{llll}
\hline Model & Dependent variable & $\chi 2$-value & p-value \\
\hline 1 & Annual dividend & 2.41 & $\mathbf{0 . 1 2 0 6}$ \\
\hline
\end{tabular}

\section{Poolability Test}

Results in Table 4.5 shows the test results for time fixed effects. There were no time related effects when the dependent variable was annual dividend since the $p$ value $>0.05$. It was not appropriate to introduce a dummy variable or use two-way analyses when annual dividend is the dependent variables.

Table 4.5. Test Results for Time Fixed Effects

\begin{tabular}{llll}
\hline Model & $\begin{array}{l}\text { Dependent } \\
\text { variable }\end{array}$ & $\begin{array}{l}\text { F- } \\
\text { value }\end{array}$ & $\begin{array}{l}\text { p- } \\
\text { value }\end{array}$ \\
\hline 1 & $\begin{array}{l}\text { Annual } \\
\text { Dividend }\end{array}$ & 1.76 & 0.0982 \\
\hline
\end{tabular}

\section{Heteroscedasticity and Serial Correlation Test}

Both heteroskedasticity and serial correlation tests were summarized as shown in Table 4.6. Heteroskedasticity was tested using modified Wald test whose results showed that there was no uniform variance since in the trio cases the $\mathrm{P}$ values were less than 0.05 therefore robust standard errors should be used to eliminate biasness. In addition, there was no evidence for serial correlation among the panels ( $\mathrm{p}$ value $>0.05)$.
Table 4.6. Result for Heteroskedasticity and Serial Correlation Test

\begin{tabular}{llllll}
\hline & \multicolumn{3}{l}{ Test for heteroskedasticity } & \multicolumn{2}{l}{$\begin{array}{l}\text { Serial } \\
\text { Correlation }\end{array}$} \\
Model & $\begin{array}{l}\text { Dependent } \\
\text { variable }\end{array}$ & $\begin{array}{l}\chi^{2}- \\
\text { value }\end{array}$ & $\begin{array}{l}\text { p- } \\
\text { value }\end{array}$ & $\begin{array}{l}\text { F- } \\
\text { value }\end{array}$ & $\begin{array}{l}\text { p- } \\
\text { value }\end{array}$ \\
\hline \multirow{2}{*}{1} & $\begin{array}{l}\text { Annual } \\
\text { dividend }\end{array}$ & 42.31 & 0.0025 & 1.586 & 0.2150 \\
\hline
\end{tabular}

\section{Multicollinearity Test}

Multicollinearity was absent since VIFs did not exceed 10 as shown in Table 4.7. Hence, multiple regression model would be fitted to evaluate the influence of profitability, capital expenditure, leverage and liquidity on dividend payout among limited liability companies in Kenya.

Table 4.7. Multicollinearity Test

\begin{tabular}{lll}
\hline Variable & VIF & Tolerance \\
\hline Profitability & 4.674 & 0.214 \\
Capital expenditure & 3.259 & 0.307 \\
Leverage & 1.793 & 0.558 \\
Liquidity & 2.329 & 0.429 \\
\hline
\end{tabular}

\section{Hausman Test}

Hausman guided on choice between random and fixed effects model. To achieve this Hausman test was applied. Results in Table 4.8 revealed that the most appropriate model to fit when annual dividend was the dependent variable was random effect since the $\mathrm{p}$ value $>0.05$.

Table 4.8. Hausman Test

\begin{tabular}{lllll}
\hline $\begin{array}{l}\text { Test } \\
\text { Summary }\end{array}$ & & $\begin{array}{l}\text { Chi-Sq. } \\
\text { Statistic }\end{array}$ & $\begin{array}{l}\text { Chi-Sq. } \\
\text { d.f. }\end{array}$ & Prob. \\
\hline & & 2.5910 & 5 & 0.7627 \\
\hline Variable & Fixed & Random & $\begin{array}{l}\text { Variable } \\
\text { (Diff.) }\end{array}$ & Prob. \\
\hline $\begin{array}{l}\text { Profitability } \\
\text { Capital }\end{array}$ & 0.4764 & 0.4571 & 0.0027 & 0.7085 \\
$\begin{array}{l}\text { expenditure } \\
\text { Leverage }\end{array}$ & -0.3952 & -0.3320 & 0.0099 & 0.5251 \\
Liquidity & 0.1793 & 0.2083 & 0.0009 & 0.3257 \\
\hline
\end{tabular}

\section{Regression Analysis}

Simple regression analysis was deployed while examining effect of each predictor while multiple modelling was used when examining joint prediction power. Random effects models were fitted as supported by Hausman test

\section{Random Effect of Profitability on Dividend Payout}

The first objective of the study evaluated the effect of profitability on dividend payout of listed non-financial companies in NSE. Results in Table 4.9 indicates that $32.8 \%$ 
of changes in dividend payout can be accounted for by profitability. Profitability has positive and significant effect on dividend payout in NSE $(\beta=0.54, \mathrm{p}$ value $<0.05)$. This was in conformity with previous studies which also found there is a connection between these variables such as Moradi et al., (2009), Adediran and Alade (2013) even though it refuted the claim of no or negative relationship by some past studies like Lee et al., (2012) and Mehta (2012). Results from correlation analysis of profitability and dividend policy had a medium strength (rho $=0.573)$. The resultant equation is of the form:

Dividend Payout $=3.02+0.54 *$ Profitability

Table 4.9. Random Effect of Profitability on Dividend Payout.

\begin{tabular}{|c|c|c|c|c|}
\hline Variable & $\begin{array}{l}\text { Coeffi } \\
\text { cient }\end{array}$ & Std. Error & $\begin{array}{l}\text { t- } \\
\text { Statis } \\
\text { tic } \\
\end{array}$ & $\begin{array}{l}\text { Pro } \\
\text { b. }\end{array}$ \\
\hline Profitability & 0.54 & 0.209 & 2.584 & 0.00 \\
\hline $\mathrm{C}$ & 3.02 & 4.166 & 0.725 & $\begin{array}{l}0.41 \\
2\end{array}$ \\
\hline R-squared & 0.328 & $\begin{array}{l}\text { Mean } \\
\text { dependent } \\
\text { variable }\end{array}$ & & $\begin{array}{l}15.4 \\
5\end{array}$ \\
\hline $\begin{array}{l}\text { Adjusted R- } \\
\text { squared }\end{array}$ & 0.264 & $\begin{array}{l}\text { S.D. dependent } \\
\text { variable }\end{array}$ & & $\begin{array}{l}1.50 \\
4\end{array}$ \\
\hline $\begin{array}{l}\text { S.E. of } \\
\text { regression }\end{array}$ & 1.902 & $\begin{array}{l}\text { Sum squared } \\
\text { residuals }\end{array}$ & & $\begin{array}{l}160 . \\
235\end{array}$ \\
\hline F-statistic & 3.542 & $\begin{array}{l}\text { Durbin-Watson } \\
\text { stat }\end{array}$ & & $\begin{array}{l}2.00 \\
1\end{array}$ \\
\hline $\begin{array}{l}\text { Prob (F- } \\
\text { statistic) }\end{array}$ & 0.000 & & & \\
\hline
\end{tabular}

\section{Random Effect of Capital Expenditure on Dividend Payout}

The second objective of the study evaluated the effect of capital expenditure on dividend payout of listed non-financial companies in NSE. Results in Table 4.10 indicates that 45.7\% of changes in dividend payout can be accounted for by capital expenditure extraneous factors may be contributing the remaining. Capital expenditure negatively and significantly contributed on dividend payout NSE $(\beta=-0.74$, p value < 0.05). These results confirmed (Ardestan et al., 2013; Tahir, et al., 2015). The resultant equation is of the form:

Dividend Payout $=2.08-0.74 *$ Capital Expenditure
Table 4.10. Random Effect of Capital Expenditure on Dividend Payout

\begin{tabular}{lllll}
\hline Variable & $\begin{array}{l}\text { Coeffi } \\
\text { cient }\end{array}$ & Std. Error & $\begin{array}{l}\text { t- } \\
\text { Statis } \\
\text { tic }\end{array}$ & $\begin{array}{l}\text { Pro } \\
\text { b. }\end{array}$ \\
\hline $\begin{array}{l}\text { Capital } \\
\text { Expenditure }\end{array}$ & -0.74 & 0.204 & -3.634 & 0.00 \\
C & 2.08 & 3.388 & 0.614 & 0.56 \\
& & $\begin{array}{l}\text { Mean } \\
\text { dependent }\end{array}$ & 15.4 \\
R-squared & 0.457 & & 5 \\
Adjusted R- & 0.431 & $\begin{array}{l}\text { S.D. dependent } \\
\text { variable }\end{array}$ & 1.50 \\
$\begin{array}{l}\text { squared } \\
\text { S.E. }\end{array}$ & of & 1.715 & $\begin{array}{l}\text { Sum squared } \\
\text { residuals }\end{array}$ & 4 \\
regression & & $\begin{array}{l}\text { Durbin-Watson } \\
\text { stat }\end{array}$ & 145. \\
F-statistic & 6.451 & 1.95 \\
$\begin{array}{l}\text { Prob (F- } \\
\text { statistic) }\end{array}$ & 0.000 & & 2 \\
\hline
\end{tabular}

Random Effect of Leverage on Dividend Payout

The third objective of the study evaluated the effect of leverage on dividend payout of listed non-financial companies in NSE. Results in Table 4.11 indicates that $28.8 \%$ of changes in dividend payout can be accounted for by leverage. There was positive and significant effect of leverage on dividend payout of listed non-financial companies in NSE $(\beta=0.85, \mathrm{p}$ value $<0.05)$. The results mirrored Al-Malakwi (2008) and Macharia (2013). The resultant equation is of the form:

Dividend Payout $=1.08+0.85 *$ Leverage.

Table 4.11. Random Effect of Leverage on Dividend Payout

\begin{tabular}{|c|c|c|c|c|}
\hline Variable & $\begin{array}{l}\text { Coeff } \\
\text { icient }\end{array}$ & Std. Error & $\begin{array}{l}\mathbf{t}- \\
\text { Statistic }\end{array}$ & Prob. \\
\hline Leverage & 0.85 & 0.299 & 2.841 & 0.00 \\
\hline $\mathrm{C}$ & 1.08 & 7.448 & 0.145 & 0.506 \\
\hline $\begin{array}{l}\mathrm{R} \text { - } \\
\text { squared }\end{array}$ & .288 & $\begin{array}{l}\text { Mean } \\
\text { dependent } \\
\text { variable }\end{array}$ & & 15.45 \\
\hline $\begin{array}{l}\text { Adjusted } \\
\text { R- } \\
\text { squared }\end{array}$ & 0.258 & $\begin{array}{l}\text { S.D. } \\
\text { dependent } \\
\text { variable }\end{array}$ & & 1.504 \\
\hline $\begin{array}{l}\text { S.E. of } \\
\text { regressio } \\
n\end{array}$ & 1.214 & $\begin{array}{l}\text { Sum squared } \\
\text { residuals }\end{array}$ & & $\begin{array}{l}154.2 \\
3\end{array}$ \\
\hline F-statistic & 7.215 & $\begin{array}{l}\text { Durbin- } \\
\text { Watson stat }\end{array}$ & & 1.887 \\
\hline $\begin{array}{l}\text { Prob (F- } \\
\text { statistic) }\end{array}$ & 0.000 & & & \\
\hline
\end{tabular}




\section{Random Effect of Liquidity on Dividend Payout}

The fourth objective of the study evaluated the effect of liquidity on dividend payout of listed non-financial companies in NSE. Results in Table 4.12 indicates that $51.3 \%$ of changes in dividend payout can be accounted for by liquidity. There was positive and significant effect of liquidity on dividend payout of listed non-financial companies in NSE $(\beta=0.91, \mathrm{p}$ value $<0.05)$. The resultant equation is of the form:

Dividend Payout $=0.32+0.91 *$ Liquidity.

Table 4.12. Random Effect of Liquidity on Dividend Payout

\begin{tabular}{|c|c|c|c|c|}
\hline Variable & $\begin{array}{l}\text { Coeff } \\
\text { icient }\end{array}$ & Std. Error & $\begin{array}{l}\text { t- } \\
\text { Stati } \\
\text { stic }\end{array}$ & $\begin{array}{l}\text { Prob } \\
\text { • }\end{array}$ \\
\hline Liquidity & 0.91 & 0.335 & $\begin{array}{l}2.71 \\
6\end{array}$ & 0.00 \\
\hline $\mathrm{C}$ & 0.32 & 2.602 & $\begin{array}{l}0.12 \\
3\end{array}$ & $\begin{array}{l}0.52 \\
6\end{array}$ \\
\hline R-squared & 0.513 & $\begin{array}{l}\text { Mean dependent } \\
\text { variable }\end{array}$ & & $\begin{array}{l}15.4 \\
5\end{array}$ \\
\hline $\begin{array}{l}\text { Adjusted } \\
\text { R-squared }\end{array}$ & 0.491 & $\begin{array}{l}\text { S.D. dependent } \\
\text { variable }\end{array}$ & & $\begin{array}{l}1.50 \\
4\end{array}$ \\
\hline $\begin{array}{l}\text { S.E. of } \\
\text { regression }\end{array}$ & 2.213 & $\begin{array}{ll}\text { Sum } & \text { squared } \\
\text { residuals } & \end{array}$ & & $\begin{array}{l}251 . \\
32\end{array}$ \\
\hline F-statistic & 8.132 & $\begin{array}{l}\text { Durbin-Watson } \\
\text { stat }\end{array}$ & & $\begin{array}{l}1.93 \\
2\end{array}$ \\
\hline $\begin{array}{l}\text { Prob }(F- \\
\text { statistic })\end{array}$ & 0.000 & & & \\
\hline
\end{tabular}

\section{Random Effects Antecedents of Dividend Payout}

In Table 4.13, 71.8\% of changes in dividend payout in NSE can be predicted by profitability, capital expenditure, leverage and liquidity. Since F statistics has $\mathrm{p}$ value $<0.05$, then these antecedents have joint significant contribution on dividend payout.

Profitability has significant positive effect on dividend payout of listed non-financial firms in NSE $(\beta=0.49$, $p$ value $<0.05)$. These results confirm the prior study by Moradi, et al., (2009) who studied 73 companies listed Tehran Securities Exchange even though the researcher applied ordinary least square. Also supporting these results are study conducted in Nigeria (Adediran \& Alade, 2013), Kenya (Muchiri, 2006; Wasike \& Ambrose, 2015). The study refuted Mehta's (2012) who had inverse effect of profitability.

The second hypothesis stated that capital expenditure had no significant effect on dividend payout. Findings indicates that capital expenditure have inverse and significant effect on dividend payout $(\beta=-0.217$ and $p$-value $<0.05)$. This is an indication while holding constant others antecedent's unit increase in capital expenditure decreases annual dividend payout by 0.217 units. The findings refuted Tahir et al.,
(2015) who documented positive contribution of investment decision on dividend payout. In contrast they echoed Ardestan et al., (2013) who had inverse effect of capital expenditure on dividend policies in Malaysia.

The third hypothesis stated that leverage has no significant effect on annual dividend payout. Positive and significant effect of leverage on dividend payout was reported $(\beta=0.398$ and p-value $<0.05)$. This is an indication while holding other antecedent's constant, unit change in leverage is associated with 0.398 increase in annual dividend payout. Although, the findings did not support (Al-Malakwi, 2008; Asif, et al., 2010) they concurred with (Farahani \& Jhafari, 2013; Macharia, 2013).

The fourth hypothesis stated that liquidity has no significant effect on annual dividend payout of listed non-financial firms in NSE. Positive and significant effect of liquidity on annual dividend payout was reported $(\beta=0.177$ and $p$-value $<0.05)$. This is an indication that unit increase in liquidity increased annual dividend payout by 0.177 units. The study contradicted Kibet (2012) but confirmed Igan, et al., (2010) and Waswa, et al., (2014) who had non-significant and significant effect of liquidity on annual dividend payout.

Table 4.13. Random Effects Regression for Antecedents of Dividend Payout

\begin{tabular}{|c|c|c|c|c|}
\hline Variable & $\begin{array}{l}\text { Coeff } \\
\text { icient }\end{array}$ & Std. Error & $\begin{array}{l}\text { t- } \\
\text { Stati } \\
\text { stic }\end{array}$ & Prob. \\
\hline Profitability & 0.490 & 0.322 & 4.521 & 0.00 \\
\hline Capital & - & \multirow{2}{*}{0.292} & - & \multirow{2}{*}{0.002} \\
\hline Expenditure & 0.217 & & 2.743 & \\
\hline Leverage & 0.398 & 0.124 & 3.205 & 0.002 \\
\hline Liquidity & 0.177 & 0.072 & 2.447 & 0.018 \\
\hline $\mathrm{C}$ & 5.01 & 7.827 & 0.639 & 0.526 \\
\hline R-squared & 0.718 & $\begin{array}{l}\text { Mean dependent } \\
\text { variable }\end{array}$ & & 13.407 \\
\hline $\begin{array}{l}\text { Adjusted R- } \\
\text { squared }\end{array}$ & 0.692 & $\begin{array}{l}\text { S.D. dependent } \\
\text { variable }\end{array}$ & & 2.1 \\
\hline $\begin{array}{l}\text { S.E. of } \\
\text { regression }\end{array}$ & 1.802 & $\begin{array}{l}\text { Sum squared } \\
\text { residuals }\end{array}$ & & $\begin{array}{l}159.05 \\
5\end{array}$ \\
\hline F-statistic & 2.712 & $\begin{array}{l}\text { Durbin-Watson } \\
\text { stat }\end{array}$ & & 1.491 \\
\hline $\begin{array}{l}\text { Prob (F- } \\
\text { statistic) }\end{array}$ & 0.006 & & & \\
\hline
\end{tabular}

The resultant model of the study is of the form:

Dividend payout $=5.01+0.490 *$ Profitability $-0.217 *$ Capital Expenditure $+0.398 *$ Leverage $+0.177 *$ Liquidity ..... (4.5).

\section{CONCLUSION}

In the review of theories and empirical literature the study found that there exists an interconnection between the amount of dividend and four independent factors under consideration. 
These factors were profitability, capital expenditure, leverage and liquidity. To start with, profitability as measured by total annual earnings after tax has similar co-movement with annual dividend payout. This means that an increase in the level of earnings after tax would result on more Dividend being paid. Another key observable determinant that affects the amount of dividend paid annual is the company investment in capital expenditure as measured by annual capital expenditure. Capital expenditure significantly influences dividend paid out negatively. This means that as the company management and shareholder choose to invest more then, they forgo dividend receipts since this reduces earning amount left to be shared. It can also be concluded as leverage as proxied by annual interest charges on long term debt had a positive and significant relationship with dividend policy as measured by the total annual dividend paid. Interest payment for long term debt takes priority as a charge on the profit made by the company, even before tax, and hence reduces the amount of profit after tax which is available for distribution to shareholders. Finally, it can also be concluded that liquidity as measured by combination of net income, depreciation, amortization, other non-cash adjustments and changes in non-cash working capital influence positively and significantly the level of dividend paid. This means that an improvement of a company's liquidity would lead to a better compensation to shareholder inform of dividend distributions.

\section{REFERENCES}

1. Adediran, S. A., \& Alade, S. O. (2013). Dividend policy and corporate performance in Nigeria. American Journal of Social and Management Sciences, 4(2), 123-145.

2. Ahmad, I., \& Muqaddas, M. F. (2016). Determinants of dividend payout policy: An Empirical Study of Banking Sector of Pakistan, Applied Studies in Agribusiness and Commerce, 10 (4), 101-106.

3. Ahmed, E. I. (2015). Liquidity, profitability and the dividends payout policy. World Review of Business Research, 5 (2), 123-134.

4. Alchian, A., \& Demsetz, H. (1972). Production, information costs, and economic organization. The American Economic Review, 62(5), 777-795.

5. Alifani, A., \& Nugroho, B. (2013). Proving Modigliani and Miller theories of capital structure: The research on Indonesian cigarette companies. International Journal of Economic Sciences, 2(3),120.

6. Al-Malakwi, H. N. (2008). Factors influencing corporate dividend decision: Evidence from Jordanian panel data. International Journal of Business,13(2), 12-25.
7. Amidu, M., \& Abor, J. (2006). Determinants of dividend payout ratios in Ghana. The Journal of Risk Finance, 7(2), 136-145

8. Arrow, K. (1971). Essays in the theory of risk bearing. Chicago, IL: Markham.

9. Asif, A., Rasool, W. \& Kamal, Y. (2010). Impact of financial leverage on dividend policy: empirical evidence from Karachi Stock Exchange-Listed Companies. African Journal of Business Management, 5(4), 12-35.

10. Badu, E. A. (2013). Determinants of dividend payout policy of listed financial institutions in Ghana. Research Journal of Finance and Accounting, 4(7), 185-190.

11. Baker, H. K., \& Haslem, J. A. (1974). Toward the development of client-specified valuation models. The Journal of Finance, 29(4), 1255-1263.

12. Baltagi, B. H., (2005). Econometric analysis of panel data. John Wiley \& Sons.

13. Banerjee, S. (2017). Determinants of dividend policy of listed information technology companies in India. Journal of Indian Management, 7 (9), 5462.

14. Bhattacharya, S., (1979). Imperfect information, dividend policy, and the bird in the hand Fallacy'. Bell Journal of Economics, 10(1), 259-270.

15. Brennan, M. J., \& Thakor, A. V. (1990). Shareholders preferences and dividend policy. The Journal of Finance, 45(4), 990-1018.

16. Easterbrook, F. H. (1984). Two agency cost explanations of dividends. The American Economic Review, 74(4), 650-659.

17. Eisenhardt, K. M. (1989). Agency theory: An assessment and review. Academy of Management Review, 14(1),57-74.

18. Fama, E., \& Jensen, M. (1983). Separation of ownership and control. Journal of Law and Economics, 26(2), 301-325.

19. Farahani, H. M., \& Jhafari, G. M. (2013). Impact of financial leverage on dividend policy at Tehran Stock Exchange: A case study in food industry. European Online Journal of Natural and Social Sciences, 2(3),35-47.

20. Gill, A., Biger, N., \& Tibrewala, R. (2010). Determinants of dividend payout ratios: Evidence from United States. The Open Business Journal, 3 (3), 8-14.

21. Greene, W. H. (2008). The econometric approach to Hausman, J. A. (1978). Specification tests in econometrics. Econometrica, 46(6), 1215- 1271.

22. Tahir, H. S., Ullah, R. M., \& Mahamood, S. (2015). Banks dividend policy and investment decision as determinants of financing decision: Evidence from 
Pakistan. American Journal of Industrial and Business Management, 5(15), 311-323.

23. Imran, K., (2011). Determinants of dividend payout policy: A case of Pakistan engineering sector. The Romanian Economic Journal, 4(41), 47-60.

24. Jiang, J., \& Jiranyakul, K. (2013). Capital structure, cost of debt and dividend payout of firms in New York and Shanghai Stock Exchanges. International Journal of Economics and Financial Issues, 3(1), 113-121.

25. John, K., \& Williams, J., (1985). Dividends, dilution, and taxes: A signalling equilibrium. The Journal of Finance, 40(4), 1053-1070.

26. Jóźwiak, B. K. (2015). Determinants of dividend policy: Evidence from polish listed companies. Procedia Economics and Finance, 23(15), 473 477.

27. Kajola, S. O., Desu, A. A., \& Agbanike, T. F. (2015). Factors influencing dividend payout policy decisions of Nigerian Listed Firms. International Journal of Economics, Commerce and Management, 3(6), 539-557.

28. Kajola, S.O, Adewumi, A.A \& Oworu, O. O. (2015). Dividend pay-out policy and firm financial performance: evidence from Nigerian listed nonfinancial firms. International Journal of Economics, Commerce and Management, 3(4), 1-12.

29. Kanwal, M. \& Hameed, S. (2017). The relationship between dividend payout and firm financial performance. Journal of Research in Business and Management, 4(1), 5-13.

30. Khan, F. A., \& Ahmad, N., (2017). Determinants of dividend payout: An empirical study of pharmaceutical companies of Pakistan Stock Exchange (PSX). Journal of Financial Studies \& Research, 10 (5), 1-16.

31. Kibet, P.K. (2012). The effect of liquidity on dividend payout by companies listed at the Nairobi Securities Exchange. MBA Thesis. University of Nairobi. Unpublished.

32. Komrattanapanya, P. \& Suntrauk, P. (2013). Factors influencing dividend payout in Thailand: A Tobit regression analysis. International Journal of Accounting and Financial Reporting. 3(2),145-152.

33. Kosgei, M. (2017). Determinants of dividend payout policy by listed companies listed in Nairobi Securities Exchange, Kenya. Journal of Business and Management, 19 (8), 46-53.

34. La Porta, R., De Silanes, F. L., Shleifer, A., \& Vishny, R. W. (2000). Agency problems and dividend policies around the world. The Journal of Finance, 55(1), 1-33.
35. Labhane, N. B., \& Das, R. C. (2015). Determinants of dividend payout ratio. Evidence from Indian companies. Business and Economic Research, 5(2), 217-241.

36. Lee, S. P., Isa, M., \& Lim, W. L., (2012). Dividend changes and future profitability: Evidence from Malaysia. Asian Academy of Management Journal of Accounting and Finance, 8(2), 147-153.

37. Macharia E. W. (2013). Determinants of dividend payout ratio in the Nairobi Securities Exchange in Kenya. Master thesis (Dedan Kimathi University of Technology).

38. Mehta, A. (2012). An empirical analysis of determinants of dividend policy -evidence from the UAE Companies. Global Review of Accounting and Finance, 3(1), 125-1.36

39. Miller, M, H., \& Rock, K. (1985). Dividend policy under asymmetric information. The Journal of Finance, 40(4), 1031-1051.

40. Miller, M. H. \& Rock, K. (1985). Dividend Policy Under Asymmetric Information. The Journal of Finance, 40 (4), 1031-1051.

41. Miller, M., \& Modigliani, F. (1961). Dividend policy, growth, and the valuation of shares. The Journal of Business, 34(4),411-433.

42. Mitnick, B. (1975). The theory of agency: The policing 'paradox' and regulatory behavior. Public Choice, 24(1), 27-42.

43. Modigiliani, F. \& Miller H. M. (1958). The cost of capital, corporate finance and the theory of investment. American Economic Review, 48(3),261-297.

44. Moradi, M., Salehi, M., \& Honarmand, S. (2009). Factors affecting dividend policy: empirical evidence of Iran. Retrieved online on https://www.google.com

45. Muchiri N. I. (2006). Determinants of dividend payout: The case of listed companies in Kenya. Master thesis (university of Nairobi).

46. Mui, T. Y., \& Mustapha, M. (2016). Determinants of dividend payout ratio: Evidence from Malaysian Public Listed Firms. Journal of Applied Environmental and Biological Sciences, 6 (6), 4854.

47. Mwangi, J. M. (2016). Effect of financial structure on financial performance of firms listed at East Africa Securities Exchanges, PHD Thesis. Jomo Kenyatta University of Agriculture and Technology.

48. Nuhu, E., Musah, A., \& Senyo, D. (2014). Determinants of dividend payout of financial firms and non-financial firms in Ghana. International Journal of Academic Research in Accounting, Finance and Management Sciences, 4(3),109-118. 
49. Olang, M. M., Akenga, G. M., \& Mwangi, J. K. (2015). Effect of liquidity on the dividend pay-out by firms listed at the Nairobi Securities Exchange, Kenya. Science Journal of Business and Management, 3 (5), 196-208.

50. Parkinson J. M., \& Waweru N. M. (2010). Paying dividends by Kenyan Companies.

51. Periyathampy, E. (2012). Determinants of dividend payout ratios: Evidence from Colombo Stock Exchange (CSE) in Sri Lanka. Accessed online on https://ssrn.com.

52. Rehman, A., \&Takumi, H. (2012). Determinants of dividend payout ratio: Evidence from Karachi Stock Exchange (KSE). Journal of Contemporary Issues in Business Research, 1(1), 20-27.

53. Ross, S. (1973). The economic theory of agency: The principal's problem. American Economic Review, 63(2), 134-139.

54. Sang, W., Shisia, A., Gesimba, P., \& Kilonzo, T. (2015). The relationship between the dividend payout ratio and the capital structure of listed Companies at Nairobi Securities Exchange, Kenya in the Industrial and Allied Sector. International Journal of Economics, Commerce and Management, 3 (10), 469-484.

55. Shleifer, A., \& Vishny, R. W. (1997). A survey of corporate governance. Journal of Finance, 52(2), 737-789.

56. Soondur, S. A. K., Maunick, D., \& Sewak, S. (2016). Determinants of the dividend policy of companies listed on the Stock Exchange of Mauritius. Accessed online on http://globalbizresearch.org

57. Spence, M. (1973). Job market signalling. Quarterly Journal of Economics, 87(3), 355-374.

58. Tabari, N. A. Y., \& Shirazi, S. (2015). Examining the determinants of dividend policy in listed companies in Tehran Stock Exchange. Indian Journal of Fundamental and Applied Life Sciences, 5(3), 2375-2382.

59. Tahir, A., \& Mushaq, T. (2016). Determinants of dividend payout: Evidence from listed Oil and Gas Companies of Pakistan, Journal of Asian Finance, Economics and Business, 3 (4) 25-37.

60. Tamimi, M., Takhtaei, N., \& Malachi, F. (2014). Relationship between firm age and financial leverage with dividend policy. Asian Journal of Finance \& Accounting, 6(2), 124-143.

61. Wasike. W.T., A. \& Ambrose, J. (2015). Determinants of dividend policy in Kenya. International Journal of Arts and Entrepreneurship, 4 (11), 71-80.

62. Waswa, C. W., Ndede, F. W. S., \& Jagongo, A. O. (2014). Dividend payout by agricultural firms in
Kenya. An Empirical Analysis of Firms Listed on the Nairobi Security Exchange. International Journal of Business and Social Science, 5(11), 6374.

63. Wilson, R. (1968). On the theory of syndicates. Econometrica, 36(1), 119-132 